\section{Prof. K. K. Mathur}

Prof. Krishna Kumar Mathur's premature death on July 18, 1936, at the age of forty-three years, has deprived India of an eminent geologist and educationist. After finishing his secondary education, Mathur joined Agra College, where he came in close contact with the inspiring personality of Prof. N. C. Nag. Later he continued his studies at the Imperial College of Science and Technology, where he took the associateship of the Royal School of Mines in mining and mining geology, and the B.Sc. degree in mining, with first-class honours, of the University of London. There, too, he stood first among the successful candidates of his group and was awarded the De la Beche Medal.

Soon after his return to India, Prof. Mathur's services were secured by the Benares Hindu University as the University professor of geology in the year 1921. There he soon established himself as a great teacher and administrator. The Department of Geology owes its growth and development to Prof. Mathur, who was its head from the very beginning. His personality attracted students from all parts of India. At Benares he built up a school of geology, which is all-India in its character. His indomitable spirit in the face of hardship and his great love for the science of geology were a source of great inspiration to his students, who are spread far and wide in India, some of them holding important offices. His colleagues in the University held him in the highest esteem, and when he was appointed principal of the College of Science, constituted in 1935, everyone was indeed very happy at the selection.

In the field of research Mathur's principal contributions comprise the petrology of the Decean Trap igneous activity. $\mathrm{He}$ carried out investigations of the various differentiates and threw much light on the genetic processes leading to the formation of the different types. His presidential address to the Geology Section of the Bombay meeting of the Indian Science Congress in 1934 on this subject will continue to be a valuable work of reference for a long time to come. His research activities also extended to stratigraphy, mineralogy and colloidal chemistry.

Amongst the scientific workers in India, Mathur held a prominent position. He was vice-president of the Geological, Mining and Metallurgical Society of India for two sessions. He was a foundation fellow of the United Provinces Academy of Sciences (now the National Academy of Sciences), the Indian Academy of Sciences, and of the National Institute of Sciences in India.

On the personal side, Prof. Mathur was a man of strong principles and high ideals. As an administrator, his sense of justice was great, which won for him love from all quarters. He was strict in imposing rules but very liberal in judging faults. $\mathrm{He}$ was simple, sincere and a great philanthropist. His purse was always open for the poor student and for the cause of science. He carried his greatness with charming modesty; he was a selfiess and conscientious worker.

\section{Prof. D. F. Fraser-Harris}

Prof. David Fraser Fraser-Harris, whose death occurred on January 3, was born on February 24, 1867, the eldest son of Mr. David Harris, of Bath. $\mathrm{He}$ studied medicine at the University of Glasgow, where he obtained the Neill Amott Prize in physiological physics in 1890 and the British Medical Association Prize on the effects of alcohol in 1892. He qualified in 1893 and for the next five years was senior assistant to the professor of physiology and Muirhead demonstrator in physiology at Glasgow. He then went to St. Andrews as acting professor of physiology until 1908. He also lectured on physiology and hygiene at Manchester and Birmingham, where he obtained the degree of doctor of science and was made a member of a committee to investigate artificial respiration apparatus.

Prof. Fraser-Harris was an original member of the Biochemical Society and president of the Scottish Microscopical Society in 1908-9. In 1911 he was appointed professor at Dalhousie University, Halifax, Nova Scotia, which he represented on the Medical Council of Canada, and he remained there until 1924, when a breakdown in health compelled him to resign his appointment.

Prof. Fraser-Harris was a lucid and prolific writer on the physiology of the nervous system and the history of medicine. In addition to being general editor of the Modern Health Series, to which he contributed "Nerves-Master System of the Body" (1927), he was author of "The Functional Inertia of Living Matter: a Contribution to the Physiological Theory of Life" (1908), "Coloured Thinking" (1928) and "Morpheus or the Future of Sleep" (1928). As member of the editorial board of Medical Life, the official organ of the American Society of Medical History, he contributed a number of interesting essays to that journal on eminent undergraduate observers, medical presidents of the Royal Society, Shakespeare's perception of the functional importance of the brain and other medico-literary topies. His interest in other branches of medicine is shown by his publication last year of a little work entitled "Aural Therapy in Relation to Deafness" and an article in the Medical Press and Circular of October 28 on "The Duke-Fingard Method as applied to the Respiratory System". He is survived by his widow and a son, a sub-lieutenant in the Navy.

\section{We regret to announce the following deaths :}

Sir John A. F. Aspinall, past-president of the Institutions of Mechanical and Civil Engineers, and also of the Institution of Civil Engineers of Ireland, on January 19, aged eighty-five years.

Prof. David Ellis, professor of bacteriology and superintendent of the Schools of Pharmacy and Bakery in the Royal Technical College, Glasgow, on January 16, aged sixty-two years.

Dr. Marshall A. Howe, director of the New York Botanical Gardens, an authority on the seaweeds and liverworts of North America, on December 24, aged sixty-nine years. 